\title{
El deceso de Ricardo Palma en los periódicos de las Hemerotecas de la Biblioteca Pública de New York y de la Biblioteca del Congreso de los Estados Unidos de Washington D. C.
}

\author{
Arnaldo Mera Ávalos \\ Pontificia Universidad Católica del Perú \\ arnaldo_mera@hotmail.com.com \\ Lima, Perú
}

\section{Resumen}

Este artículo presenta por primera vez la noticia y las imágenes de los obituarios y notas necrológicas que se han podido ubicar en una primera aproximación en dos importantes hemerotecas de los Estados Unidos de América, la de la Biblioteca Pública de New York y la de la Biblioteca del Congreso de Washington D. C. En la primera se pudo hallar la noticia sobre el deceso de don Ricardo Palma en cuatro periódicos norteamericanos, y en la segunda, en otro informativo norteamericano más y en la prensa mexicana, chilena y argentina. No se encontraron referencias en la prensa madrileña, pero sí se hallaron informaciones sobre la convulsionada situación política que atravesaba nuestro país en aquellos días. Además, agregamos una imagen de otro periódico norteamericano cedida gentilmente por un colega palmista y como introducción hacemos un breve acercamiento a la obra de nuestro tradicionista en Norteamérica.

Palabras Clave: Muerte de Ricardo Palma, obituarios, notas necrológicas, periódicos 1919, historia del periodismo.

\section{Abstract}

The present article introduces for the first time the news and the images of the obituaries and death notices that could be found as a first approach in two important libraries of the United States of America, the New York Public Library and the Library of Congress in Washington D.C. There were no references found in Madrid's media, but 
there was information about the convulsed political situation that our country was going through those days. In addition, we include an image from another American newspaper kindly provided by a palmista colleague, and as an introduction, we make a brief approach to the work of our traditionist in North America.

Keywords: Ricardo Palma's death, obituaries, death notices, 1919 newspapers, history of journalism.

\section{Arnaldo Mera Ávalos (Perú)}

Bachiller en Historia y Derecho, licenciado con mención en Historia por la Pontificia Universidad Católica del Perú con la tesis Las Pulperías en Lima ante el impacto de las reformas borbónicas (2014), donde cursó estudios de maestría en Historia y Derecho Constitucional. Es miembro asociado del Instituto Riva Agüero y miembro de número del Instituto Ricardo Palma. Ha publicado «Ecuador y Perú: espacios regionales del siglo XIX»; Pulperas, chinganeras y chicheras en la Lima republicana (18301860); La armas del rey de España en sus dominios del Perú (15321824); Cronología de Carlos A. Romero, entre otros artículos de historia del Perú, siglos XVIII y XIX. 


\section{La obra de Ricardo Palma y los norteamericanos}

Nos interesó buscar los obituarios que aparecieron en los periódicos norteamericanos ya que nuestro tradicionista era ampliamente conocido por su obra no solo en los medios académicos, sino también por un público en general de los Estados Unidos de Norteamérica, que lo venía leyendo por lo menos desde 1876. Como bien señala mi profesor de maestría de Historia en la Pontificia Universidad Católica del Perú (PUCP) y destacado palmista, el Dr. Oswaldo Holguín, desde aquel año en adelante «circularon con general aprecio del público lector de habla inglesa los relatos que escribía Palma a instancia de directores y editores de diarios y revistas» (2001, p. 87). Asimismo, otro docente de la PUCP, el académico y palmista, Dr. Alberto Varillas Montenegro, en el estudio preliminar de la edición del Demonio de los Andes de la Academia Peruana de la Lengua del año 2016, señala:

Las colaboraciones de Palma llegaron también a Las Novedades, revista que se publicaba en New York dirigida por el periodista español José G. García. Las Novedades era un semanario publicado en castellano que circuló entre 1876 y 1918. En 1883 aparece en esta revista la primera colección de tradiciones que conforman El Demonio de los Andes (2016, p. XI)

Las que aparecieron en la sexta serie, para cuyo análisis deberá revisarse a Julio Díaz Falconí y Cecilia Moreano.

Sabemos por el testimonio del propio Palma, reproducido por el palmista Díaz Falconí, que las ediciones de sus relatos y tradiciones se podían encontrar en las librerías norteamericanas, pues habla de ello en una carta dirigida al médico Dickson Hunter, residente en Arequipa: 
La literatura no da pan en el Perú [...] todos entintan la pluma por puro amor al arte [...]. Son los amigos los que menos compran un libro y hasta se ofenden cuando el autor no se los regala. Y lo peor es que ni aun regalado lo leen (En Díaz Falconí, 1967, p. 43).

Y continúa afirmando nuestro tradicionista:

No sacaría ni los gastos de impresión sino tuviese mi público en el extranjero. Entre Buenos Aires y Montevideo, Santiago, México y Nueva York coloco de seiscientos a setecientos ejemplares de cada libro mío, y a pesar de las socaliñas y otras trampas de libreros logro reembolsar el capital invertido (ibíd.).

Asimismo, tenemos la acuciosa investigación del palmista Dr. Carlos Arrizabalaga, quien no solo reprodujo la carta antes mencionada (2015, pp. 21-22) en la investigación sobre un estudio de la primera traducción al inglés de un relato de Palma, aparecido en un periódico de California de 1893 (ibíd., pp. 19-40), publicada en la Revista de la Facultad de Humanidades y Lenguas Modernas, $\mathrm{N}^{\circ}$ 18; sino que también nos brinda información adicional:

Aunque no era, por supuesto un autor desconocido para el público y los intelectuales norteamericanos hasta el punto que varios profesores norteamericanos visitaron a Ricardo Palma ya anciano en su casa de Miraflores, entre ellos el historiador Charles E. Chapman, connotado historiador de Berkeley (ibíd., p. 20)

Holguín, en su artículo «Los amigos Yanquis de Palma» publicado primero en El Comercio, el 28 de setiembre de 1982 y reproducido en el libro Páginas sobre Ricardo Palma, publicado por la Universidad Ricardo Palma (URP) en el 2001, nos dice: 
En 1919, año de su muerte, Palma fue entrevistado en su casa de Miraflores por dos notables escritores yanquis: William Belmont Parker y Sturgis Elleno Leavitt. Parker había recibido el encargo de la Sociedad Hispánica de América de dar forma a un libro de biografías de peruanos contemporáneos. [...] Leavitt vino también en misión especial: realizar una investigación bibliográfica sobre la literatura peruana colonial y republicana $[\ldots]$ ha quedado referido en un artículo publicado póstumamente. Allí consigna que Palma se interesó vivamente por los intelectuales norteamericanos que lo habían visitado los últimos años, sobre todo por los notables historiadores Charles E. Chapman, de la Universidad de California; y William R. Shepard, de la de Columbia (2001, pp. 33-34).

Arrizabalaga nos dice que «El hispanista Sturgis E. Leavitt asistió a sus honras fúnebres en la iglesia de La Merced» (2015, p. 20) y en una nota a pie de página nos da el acucioso dato de que aquel testimonio póstumo lo publicó Leavitt en Hispanic American Historical Review, 2, 1920, pp. 63-67, y luego se reprodujo en Hispania 34, No 4, nov. 1951, pp.349-353" (ibíd.).

Finalmente, Arrizabalaga dice:

Al celebrarse el centenario de Palma, Manuel Pedro Gonzales, profesor de la Universidad de California en L. A., reconocía que Palma tenía «un sentido ecuménico de la cultura hispana» (1935: 25) y resaltaba «su noble ideal de fraternidad» (1935: 26) especialmente apreciado en los círculos intelectuales de las universidades americanas (ibíd., p. 23). 


\section{El deceso del tradicionista en los periódicos de la BPNY}

La importancia de nuestro egregio limeño podemos verla en las diferentes locaciones de la Unión en las cuales se anunció su deceso, así tenemos los siguientes:

2.1 New York: Aquí se anunció su deceso con nombre propio subrayado en negrita en la segunda noticia de la cuarta columna de la página 8 de la edición del miércoles 8 de octubre de 1919 del New York Tribune. Recuerdo que el anciano bibliotecario encargado de la Sala de Periódicos de dicha hemeroteca, prácticamente, me llevó como a un niño de la mano al decirme que esas noticias internacionales de importancia no eran publicadas en el Times sino en el Tribune y así obtuvimos la impresión de la toma para el presente artículo, página completa (Fig. 1).

2.2 Washington D. C.: En la capital del extenso país del norte, la noticia del deceso apareció en la parte final de la tercera columna de la primera página del Evening Star del martes 7 de octubre de 1919; en el encabezado de la noticia en inglés figuró la muerte del «Autor Peruano», en letras negritas y en la noticia misma de 4 líneas su nombre propio y ser autor de las Tradiciones (Fig.2).

Estas dos noticias fueron ya referenciadas por primera vez por Arrizabalaga (2015, p. 23) en su artículo ya mencionado de la revista de esta misma casa de estudios.

2.3 Norwich Connecticut: Aquí el anuncio de la muerte de Palma apareció en la primera página, en la sexta columna, en la sección telegramas condensados, como décimo telegrama resumido con nombre propio del Norwich Bulletin, del estado de Connecticut, del jueves 9 de octubre de 1919; en este periódico además de señalarse el volumen LXI-241, figuraba el número de habitantes de aquel poblado que ascendía a 29919 por aquel entonces (Fig. 3). 
El deceso de Ricardo Palma en los periódicos de las Hemerotecas de

la Biblioteca Pública de New York y de la Biblioteca del Congreso de LOS EStados UNIDOS DE WASHington D. C.

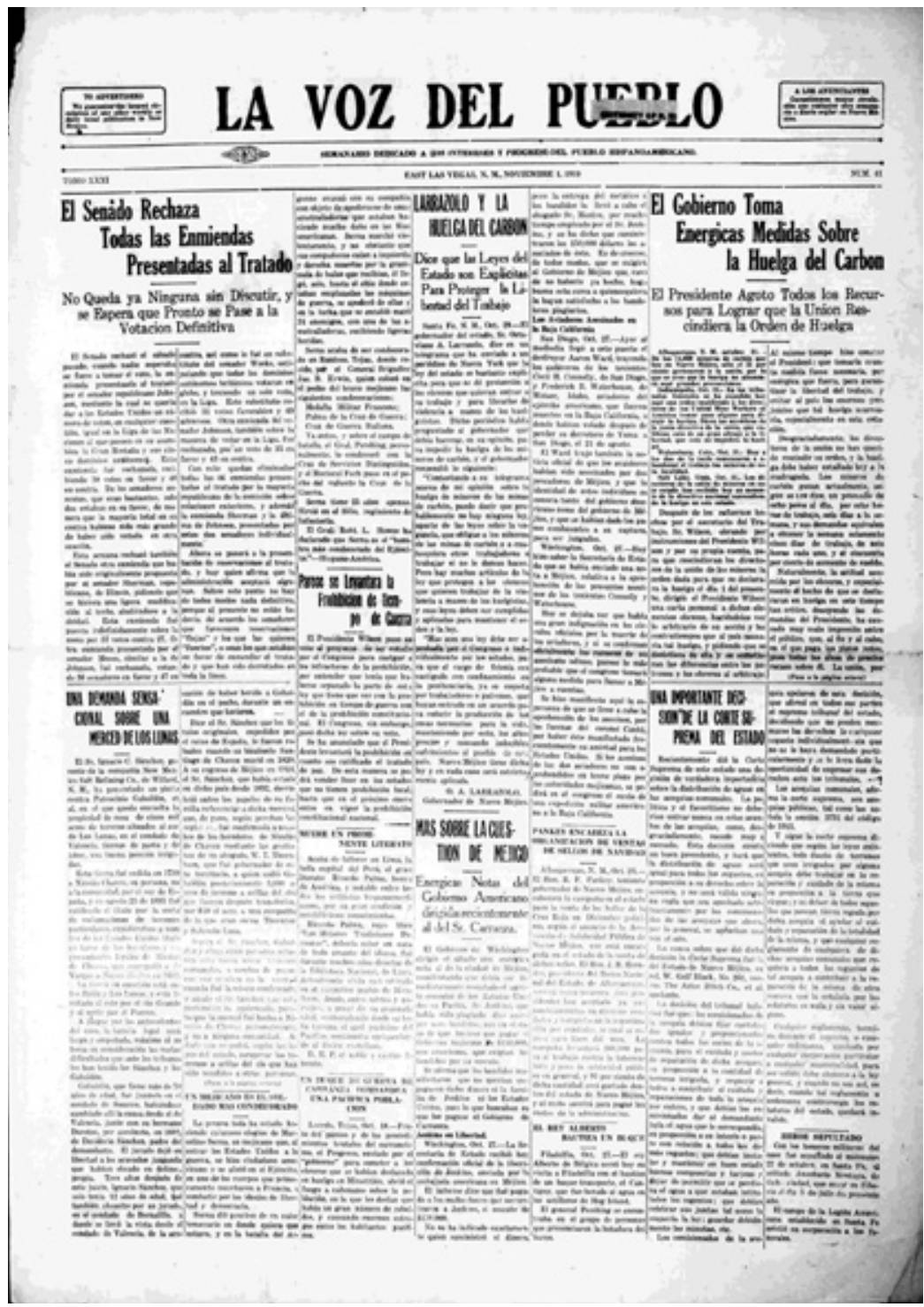

Foto 1. "Muere un prominente literato".

Fuente: Semanario La Voz del Pueblo. (Noviembre 1919). Pag 41. 


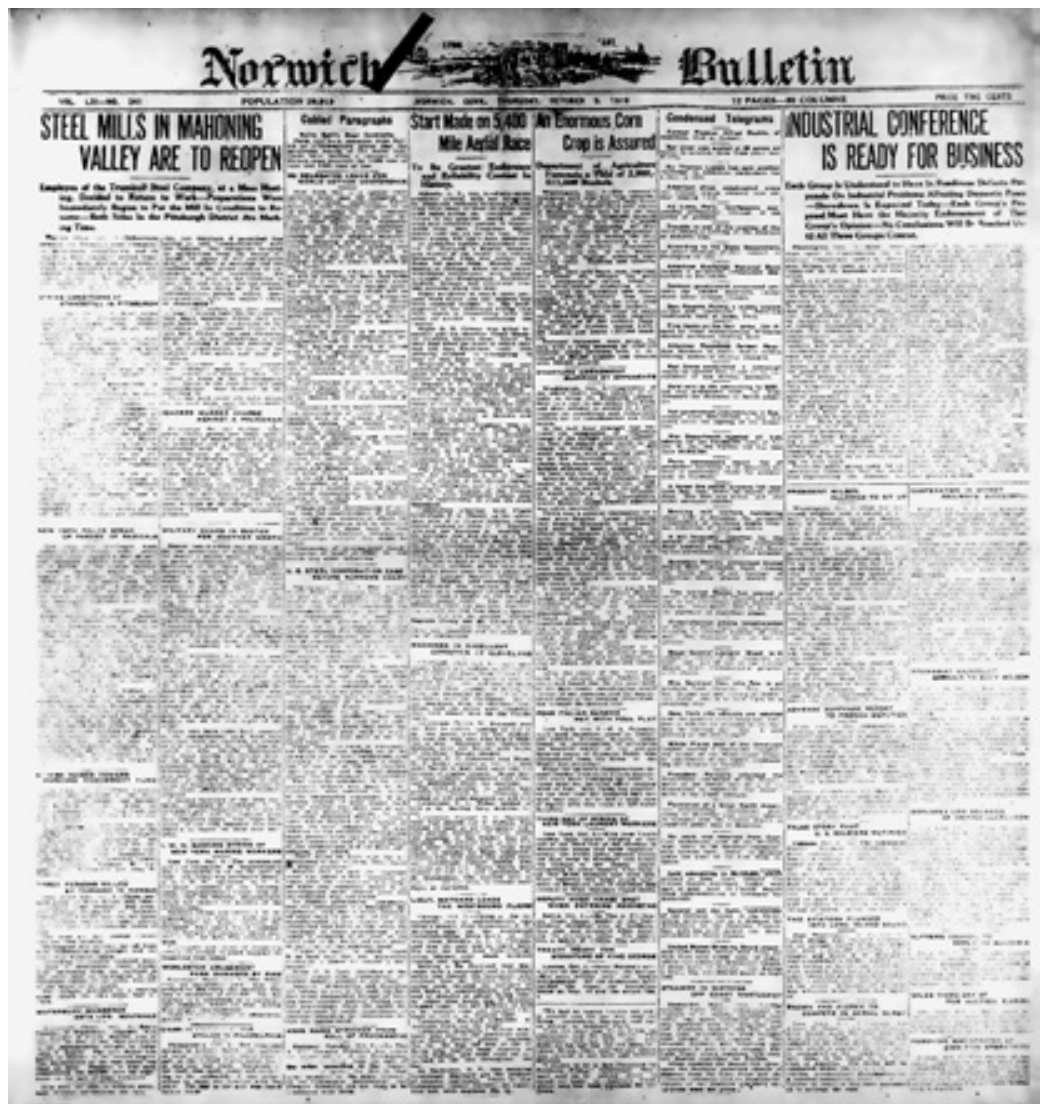

Foto 2.

Fuente: Norwich Balletin (Octubre 1919) Vol LXI.

$\mathrm{N}^{\circ} 24 \mathrm{l}$. 
El DeCeso de Ricardo Palma en los periódicos de las Hemerotecas de

la Biblioteca Pública de New York y de la Biblioteca del Congreso de LOS ESTADOS UNIDOS DE WASHINGTON D. C.

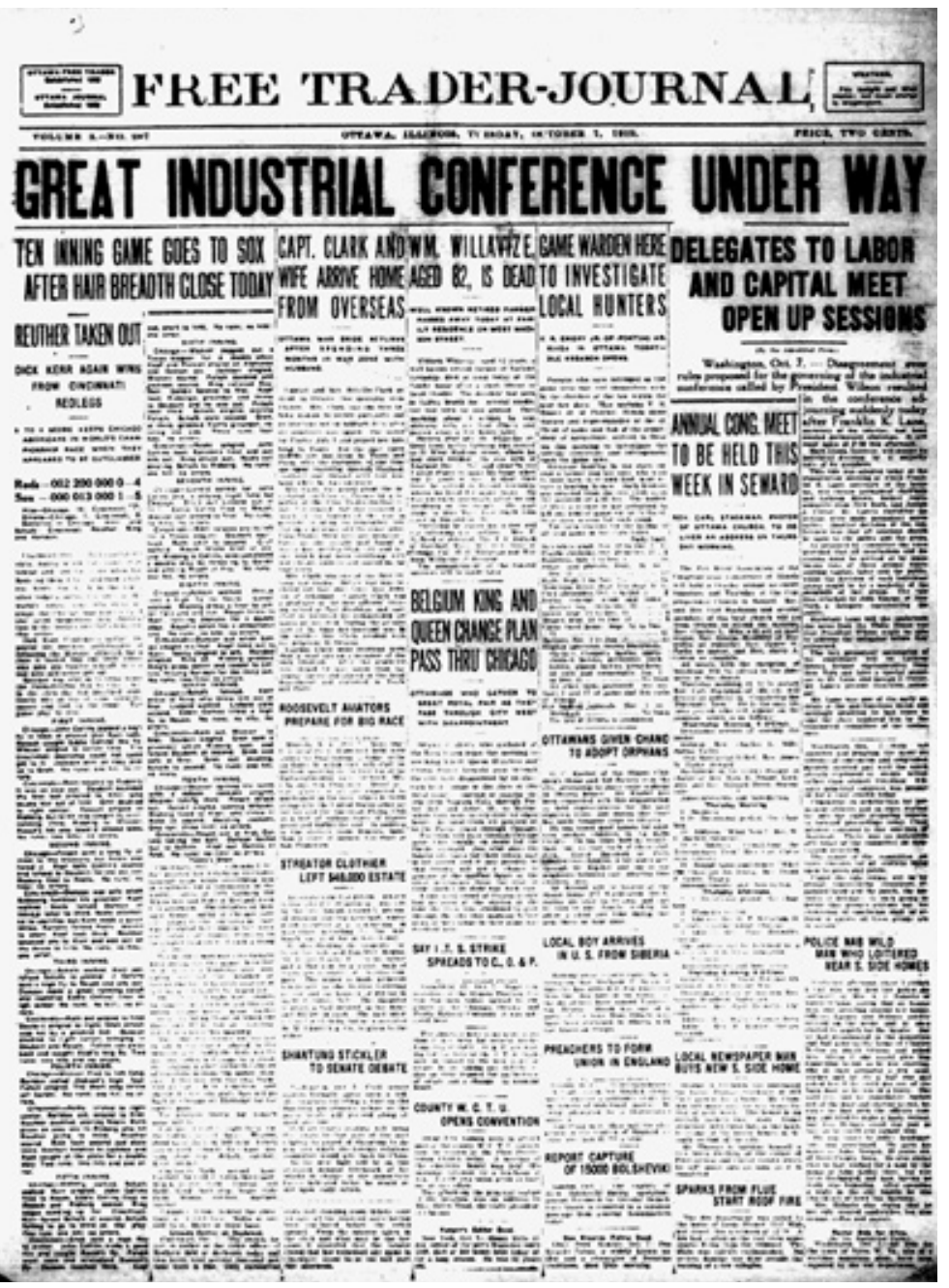

Foto 3.

Fuente: Free Trader Journal (Octubre 1919) Otawa-EEUU Vol 3. № 287. 
2.4 Ottawa, Illinois, USA: Aquí la información del fallecimiento del tradicionista apareció en la quinta columna, sexta noticia y última de la primera página del Free TraderJournal del martes 7 de octubre de 1919. Es interesante que aquí aparezca la noticia con el título en negrita que traducido sería: «Don Ricardo Palma muere», y cuatro líneas del texto. Debo destacar que el lugar donde se difundió la noticia del deceso de nuestro insigne escritor suena remoto inclusive para un peruano de la actualidad (que a veces solo ubica a la ciudad de Chicago en aquel Estado) y, por ello, es señal de orgullo el imaginar que los redactores de aquel periódico lo conocían bien, ya que pusieron su nombre propio en el encabezado de la noticia y apareció en la primera página del periódico local (Fig.4).

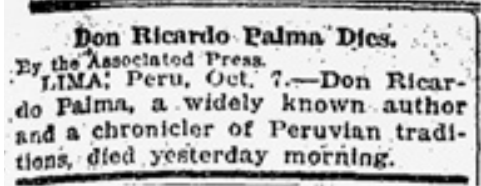

Reproduced with permission of the copyright owner. Further reproduction prohibited without

Foto 4.

Fuente: Free Trader Journal (Octubre 1919) Otawa-EEUU. Vol 3. № 287.

Adenda: El bibliotecario neoyorquino tuvo la gentileza de imprimir las tres imágenes en toma de acercamiento para poder leer la noticia del deceso, pero debido a su avanzada edad olvidó poner la referencia y de hacérmelo notar. Íbamos a subsanar esta falta en este año del 2020, pero debido a la pandemia de la covid-19, el viaje se vio frustrado y he decidido incluirlas por el gesto que tuvo ese amable bibliotecario. 
La primera imagen de esta adenda neoyorquina es la noticia del día 7 de octubre: muere don Ricardo Palma (Fig.5).

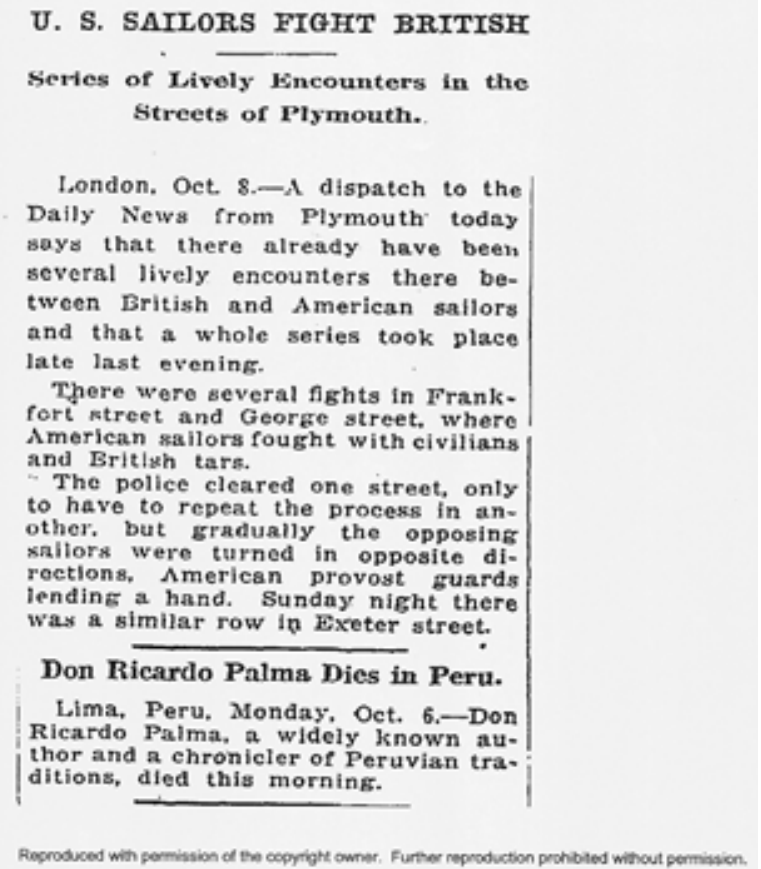

Foto 5.

Fuente: U. S. Sailors Fight British (Octubre 1919) New York - EEUU

La segunda imagen de esta adenda neoyorquina corresponde a de una noticia del día 8 de octubre y la siguiente noticia tiene fecha del 6 de octubre, Don Ricardo Palma muere en Perú, y en las tres líneas de la misma se dice que era autor y cronista de las tradiciones (Fig. 6). 

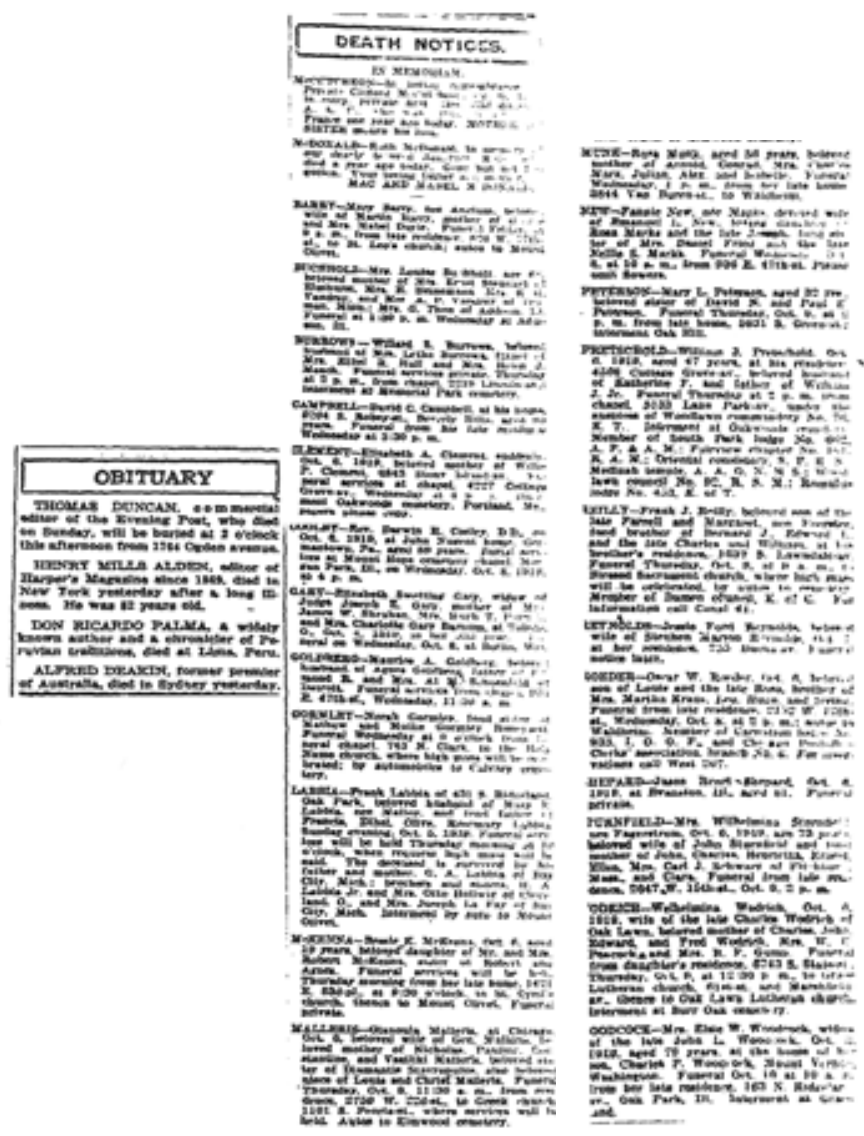

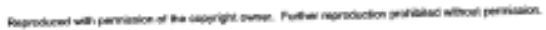

Foto 6.

Fuente: U. S. Sailors Fight British (Octubre 1919) New York - EEUU 
El deceso de Ricardo Palma en los periódicos de las Hemerotecas de

la Biblioteca Pública de New York y de la Biblioteca del Congreso de los Estados Unidos de Washington D. C.

La última imagen de esta adenda indica un obituario de editores o escritores y menciona a Palma en tercer lugar, luego de Thomas Duncan, editor del Evening Post; Henry Mills Alden, editor del Harper Magazine; y a continuación, nuestro ilustre tradicionista (Fig.7).

torsagot7

Croniding Amerce - The Lerey of Congen

The Topeka state journal. (Topeka, Kan.) 1892-1980, October 07, 1919, HOME EDITION, Page 5, Image 5

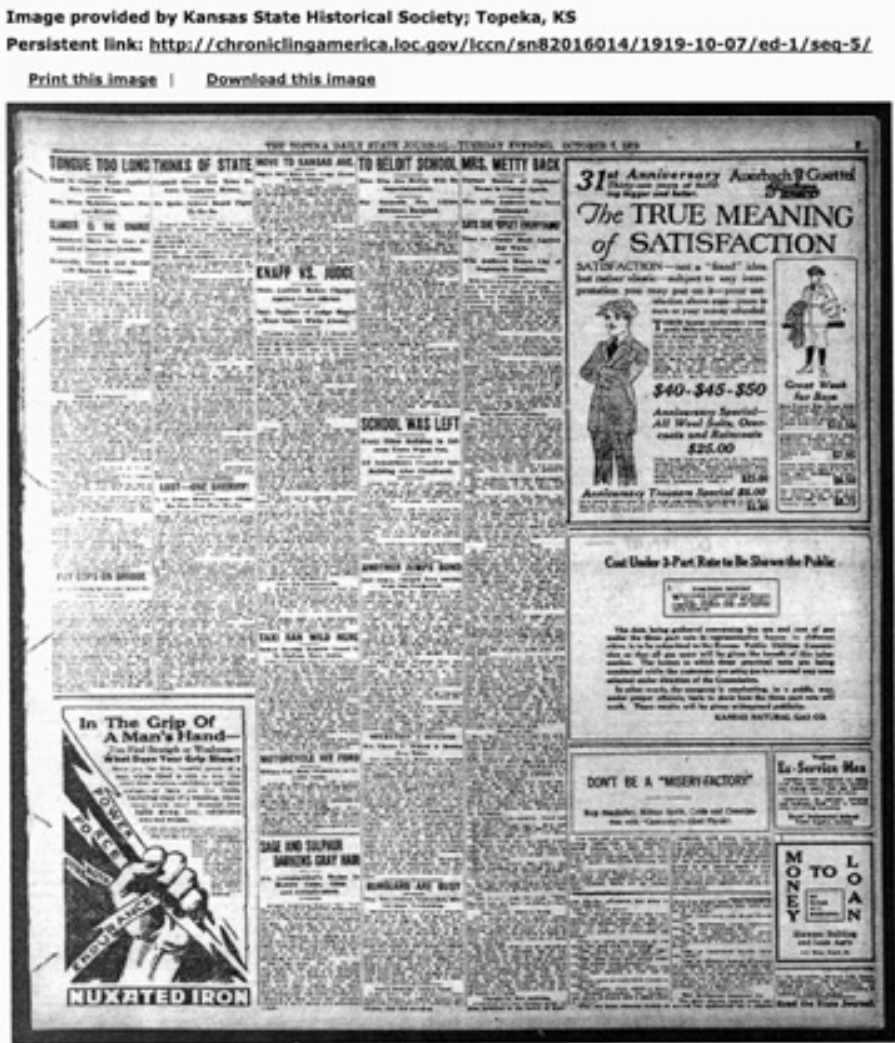

Foto 7.

Fuente: The Topeka Daily State Journal (Octubre 1919) Kansas 
Así tenemos que en esta hemeroteca encontramos cuatro publicaciones del deceso registradas y tres no registradas publicadas en los Estados Unidos.

\section{El deceso del tradicionista en los periódicos de la Biblioteca del Congreso de DC}

En la hemeroteca de la biblioteca del Congreso se me explicó que por Internet tenían acceso a todos los repositorios nacionales en la web y se me indicó que la búsqueda era compleja; para muestra, el bibliotecario nos imprimió la noticia del deceso.

3.1 En la ciudad de Topeka del Estado de Kansas encontramos que en el Topeka State Journal la información de la muerte de nuestro autor fue publicada como última noticia de la cuarta columna de la página 5 del día 7 de octubre de 1919. Aquel periódico se imprimía desde 1982 (Fig. 8) la noticia está en aumento (Fig. 9).

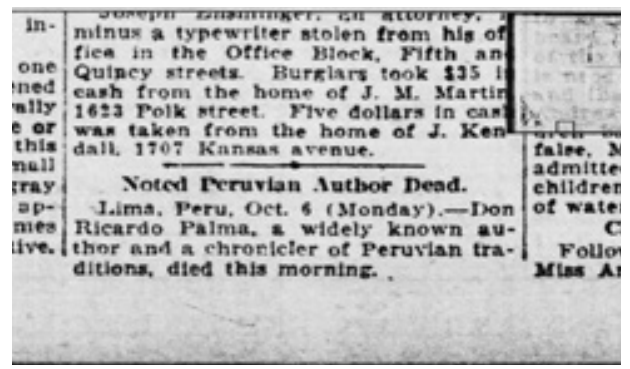

Foto 8.

Fuente: The Topeka Daily State Journal (Octubre 1919) Kansas 
El deceso de Ricardo Palma en los periódicos de las Hemerotecas de

la Biblioteca Pública de New York y de la Biblioteca del Congreso de LOS ESTADOS UNIDOS DE WASHINGTON D. C.

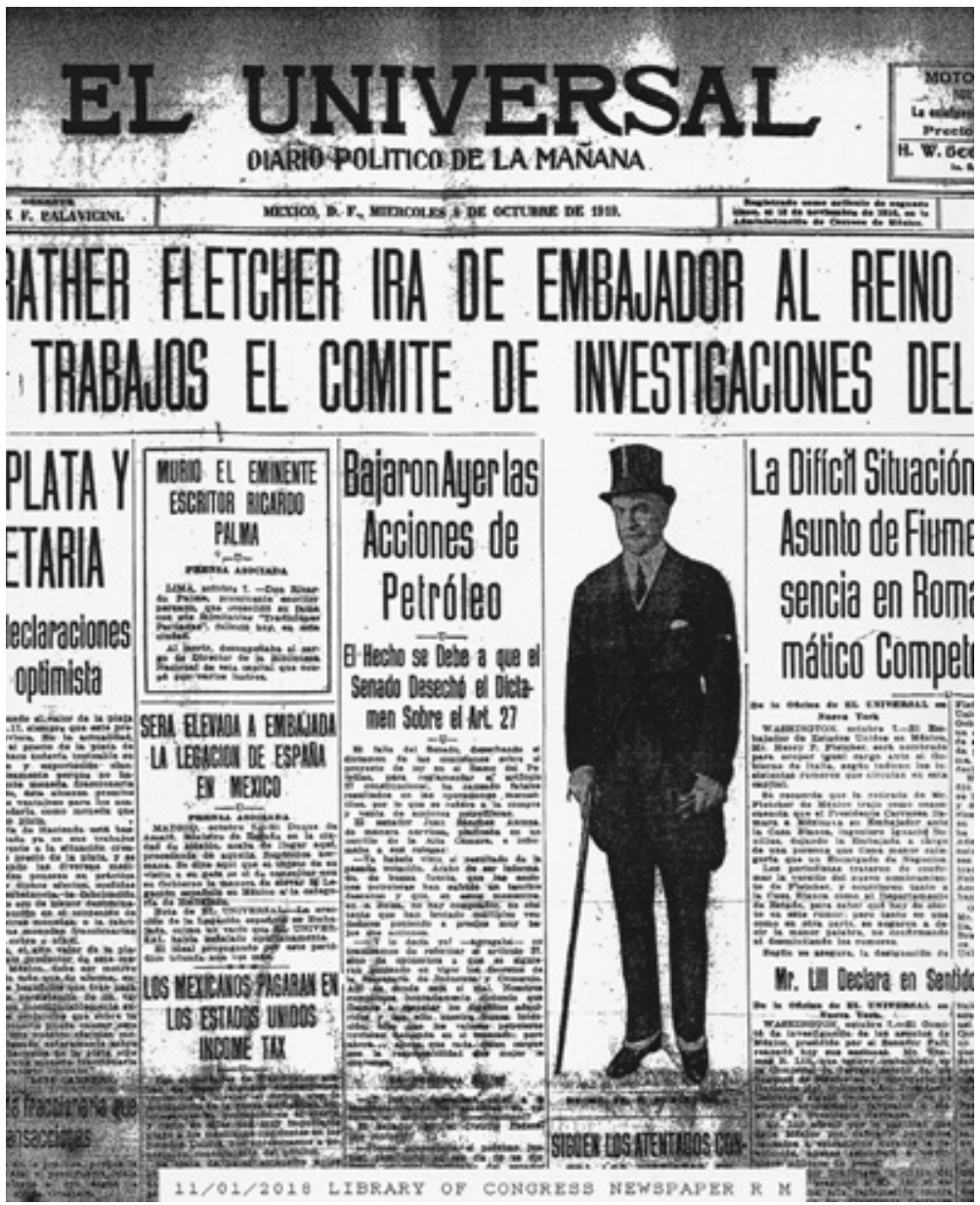

Foto 9.

Fuente: Diario El Universal (Octubre 1919) México D.F. 
La noticia del deceso en la colección de microfilms de los periódicos de países de habla hispana de la hemeroteca:

México:

3.2 La primera noticia del deceso que encontramos publicada en México D. F. se encuentra en la primera página de El Universal, diario político de la mañana, del miércoles 8 de octubre de 1919, año IV, Tomo XIII, No 1085 (Fig. 10).

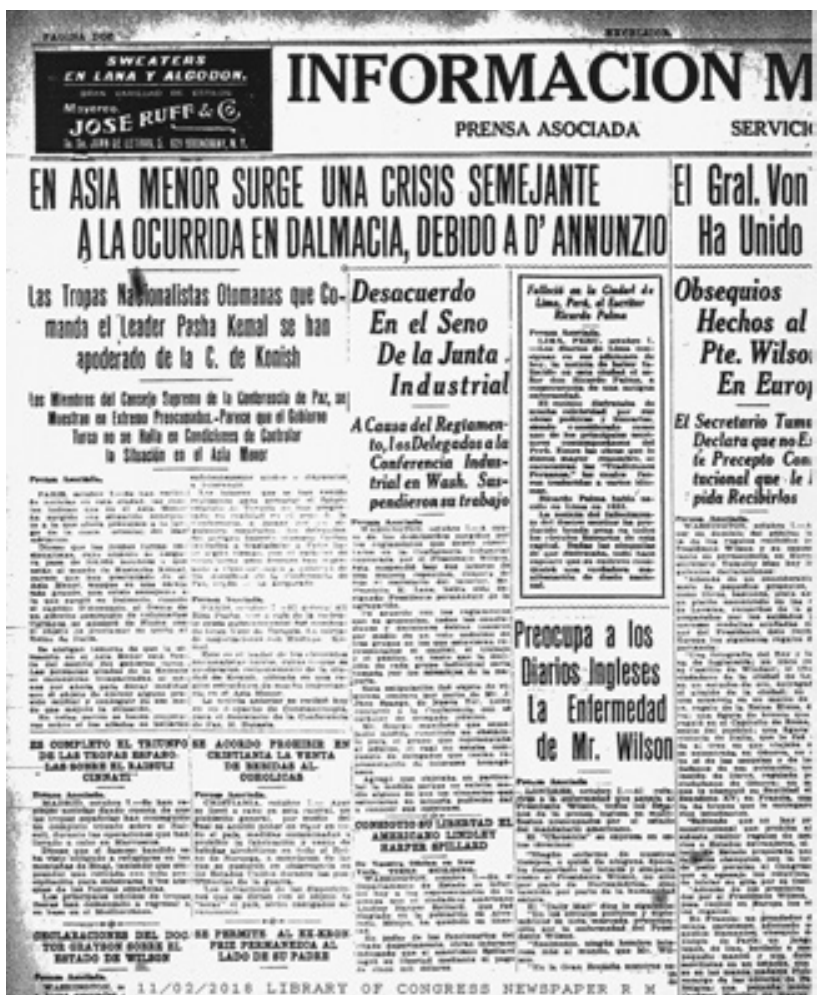

Foto 10 .

Fuente: Diario El Universal (Octubre 1919) México D.F. 
3.3 La segunda noticia del deceso en México D. F. apareció en Excelsior, del miércoles 8 de octubre de 1919, Año III, Tomo IV, No 935, página 2 (Fig. 11 ).

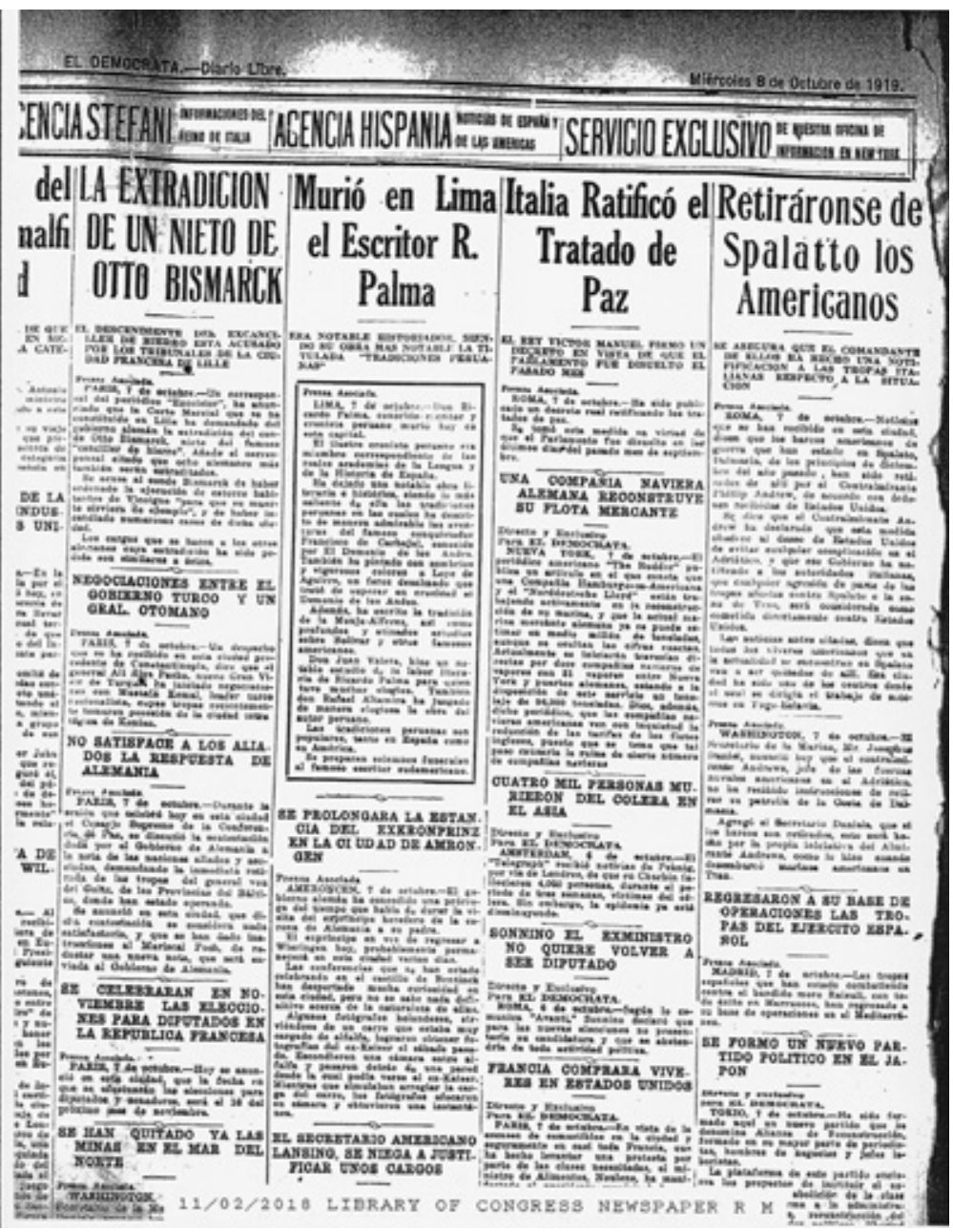

Foto 11 .

Fuente: Diario El Demócrata (Octubre 1919) México D.F. 
3.4 La tercera noticia del deceso en México D. F. apareció en El Demócrata, diario libre de la mañana, del miércoles 8 de octubre de 1919, Tomo V, No 961, página 4, (Fig. 12).

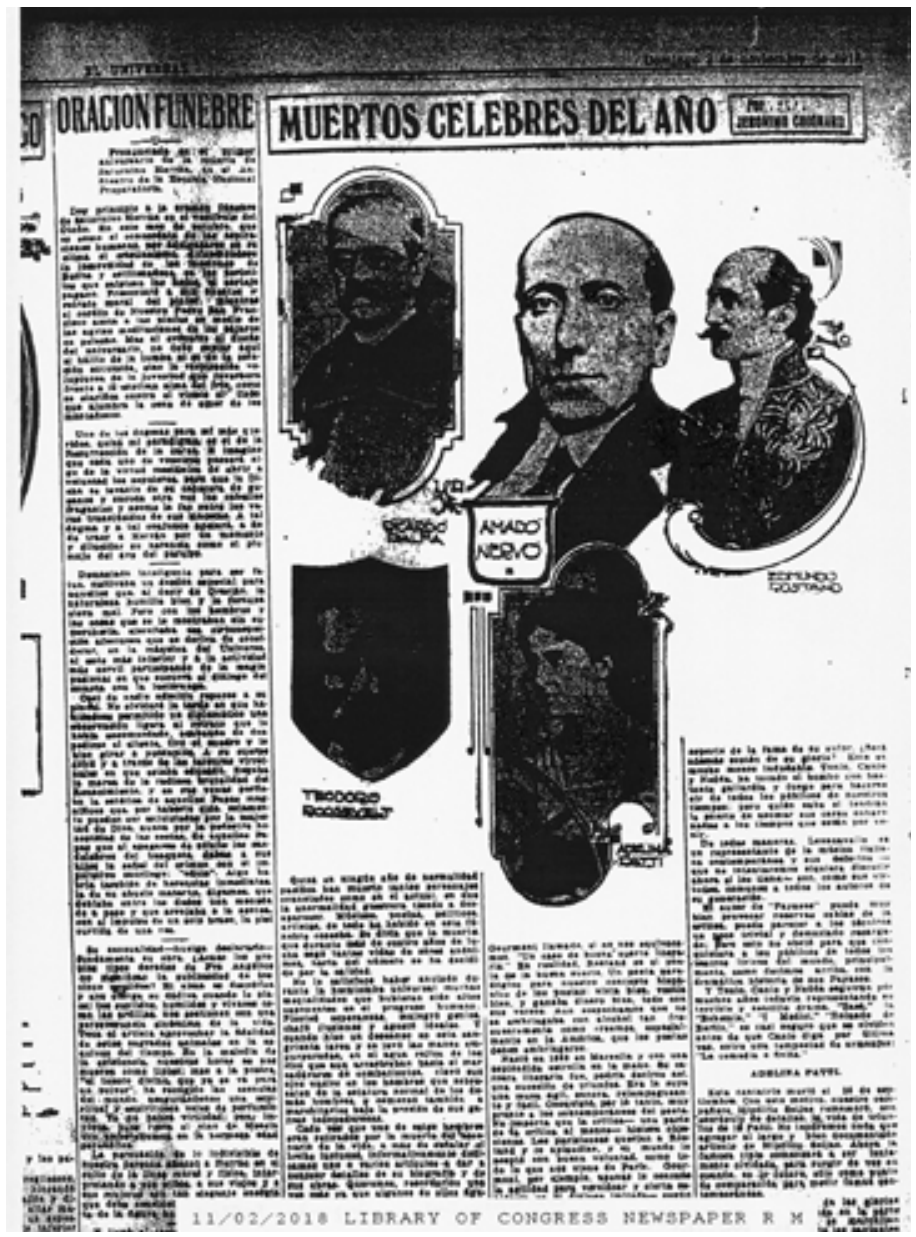

Foto 12.

Fuente: Diario El Demócrata (Octubre 1919) México D.F. 
3.5 En El Universal del domingo 2 de noviembre de 1919, el periodista Jerónimo Colonaro escribió un artículo titulado «Muertos célebres del año», como un homenaje al día de los muertos, en el cual aparece la imagen del tradicionista y le dedica los últimos tres párrafos de su artículo:

Ricardo Palma murió hace muy pocos días. Para los que supimos desde lejos la luctuosa noticia, la muerte de Ricardo Palma fue apenas un accidente histórico: el ilustre bibliotecario de la «Biblioteca Nacional de Lima» se había metido tanto en el pasado que apenas vivía realmente en el presente. Sus frecuentes tratos con oidores visorreyes, maestrescuelas, inquisidores y reales visitadores casi habían dado a Ricardo Palma prestigio de antepasado. El que conocía tan bien los tiempos que fueron, ingresó de seguro en ellos con una sonrisa de tranquilidad, como quien regresa a una vieja casa, muy frecuentada antaño. Y hasta es probable que allá en el cielo, las damas de la colonia que con tanto arte evocó en sus obras, le dijeran, aprovechando un instante favorable y golpeándole ligeramente el brazo con los grandes abanicos de pluma y moral: -Es usted algo indiscreto, mi señor don Ricardo.

(Fig. 13 y Fig. 14). 


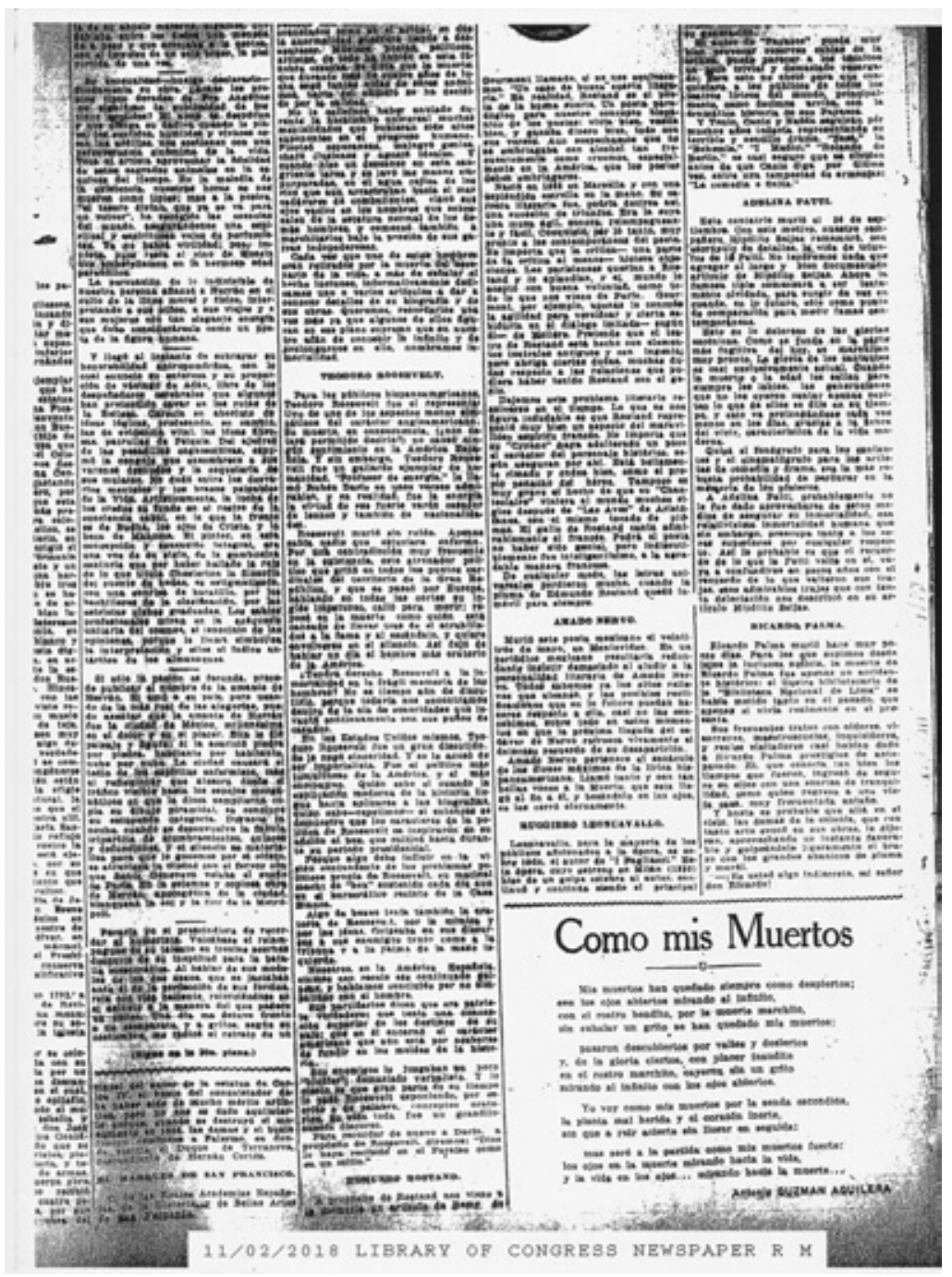

Foto 13.

Fuente: Diario El Universal (Noviembre 1919) México D.F. 
El deceso de Ricardo Palma en los periódicos de las Hemerotecas de

la Biblioteca Pública de New York y de la Biblioteca del Congreso de Los Estados Unidos de Washington D. C.

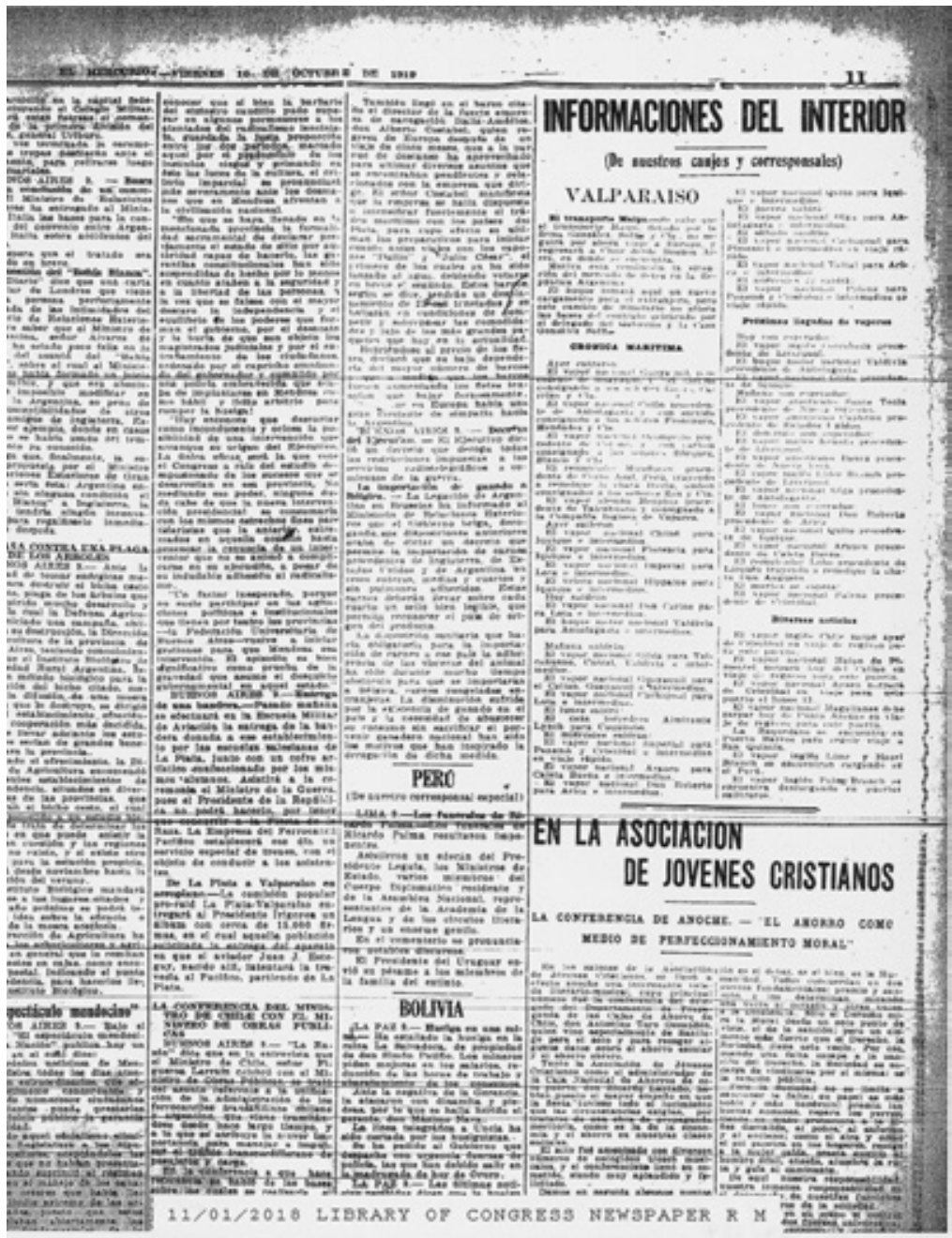

Foto 14.

Fuente: Diario El Universal (Noviembre 1919) México D.F. 


\section{Chile:}

3.6 Encontramos una interesante y breve nota del corresponsal especial a los funerales del tradicionista en una sección de la noticias correspondiente a países sudamericanos en la edición de El Mercurio, Año LXXXXIII, no 29 034, y que además tiene otra numeración, Año XX, No 6 741, del viernes 10 de octubre de 1919, en la cual de manera concisa se relató lo siguiente:

Los funerales de Ricardo Palma resultaron imponentes. Asistieron un edecán del Presidente Leguía, los Ministros de Estado, varios miembros del Cuerpo Diplomático y de la Asamblea Nacional. Representantes de la Academia de la Lengua y de los círculos literarios y un enorme gentío. En el cementerio se pronunciaron notables discursos. El Presidente del Uruguay envió su pésame a los miembros de la familia del extinto.

\section{Argentina:}

3.7 Encontramos un extenso obituario en La Prensa, del martes 7 de octubre de 1919, en la cual aparece su foto y una cruz señalando el lugar del deceso en Miraflores (Fig. 15).

\section{España:}

No encontramos ninguna referencia al deceso del tradicionista en los siguientes periódicos madrileños: El Sol, La Época, El Debate y El Imparcial para el mes de octubre de 1919. Pero hallamos las siguientes noticias referentes a nuestro país en El Sol; siendo la primera de ellas la aparecida en la edición del año III, $N^{\circ} 673$, 
El deceso de Ricardo Palma en los periódicos de las Hemerotecas de

la Biblioteca Pública de New York y de la Biblioteca del Congreso de LOS ESTAdos UNIDOS DE WASHINGTON D. C.

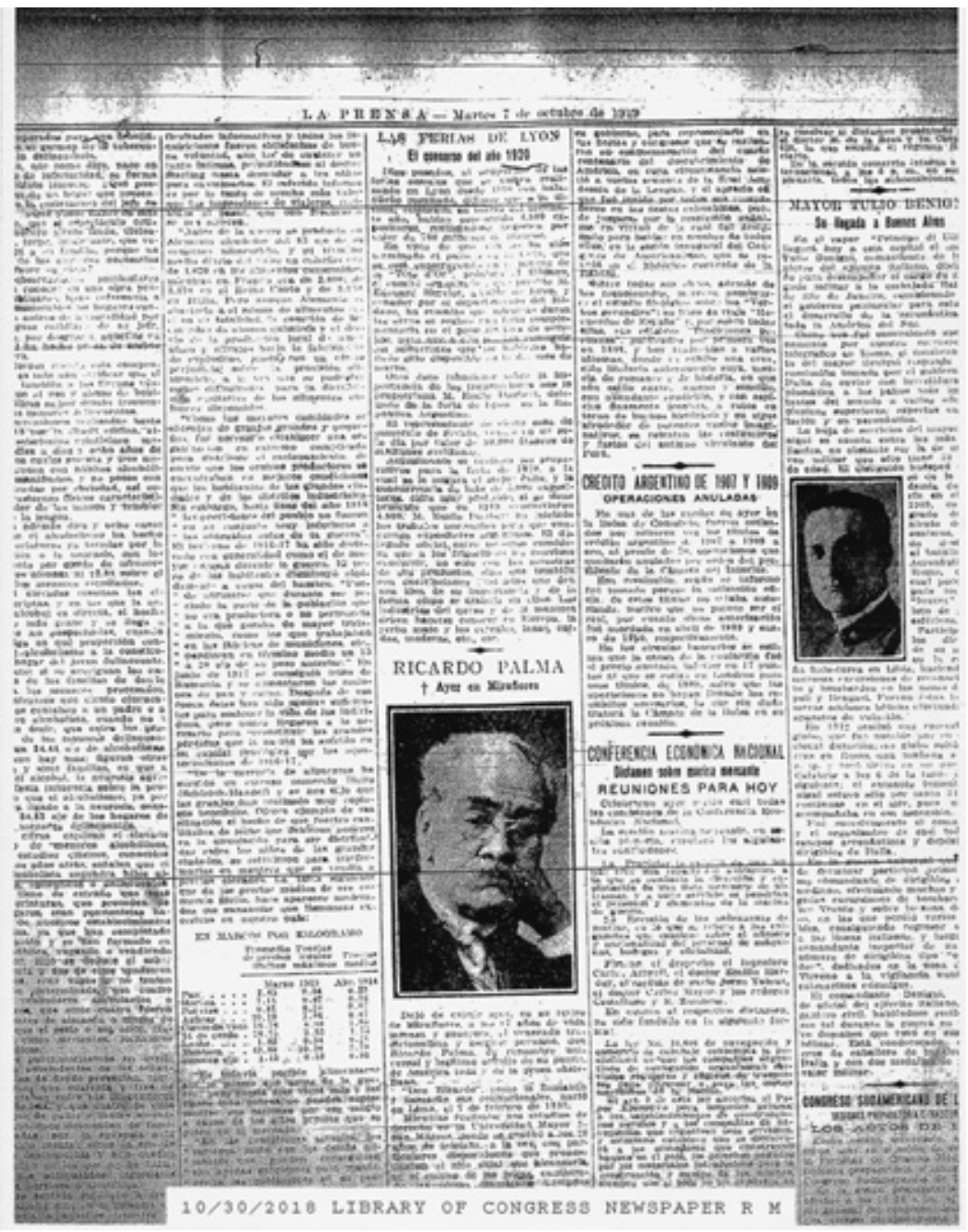

Foto 15.

Fuente: Diario La Prensa (Octubre 1919) Argentina 
del jueves 9 de octubre de 1919 con un titular en letras grandes: «Grave Situación en el Perú, los obreros electricistas en huelga», noticia del 7 de octubre; página 8 .

La segunda nota informativa apareció en el mismo periódico en la sección «Noticias del Extranjero, Noticias de Iberoamérica» con grandes letras bajo el título de «Graves huelgas en el Perú»; en $E l$ Sol año III, Nº 675, del sábado 11 de octubre de 1919, página 6.

La tercera hace mención a la juramentación que hizo el Presidente Leguía ante la Asamblea Nacional, el 14 de octubre, y aparece en $E l$ Sol, año III, No 680, del jueves 16 de octubre de 1919 , página 6.

Al día siguiente, en la misma sección de noticias de Iberoamérica, nos dice que las comunicaciones habían quedado restablecidas entre nuestro país y el exterior, la noticia provenía de La Paz, Bolivia; en El Sol, año III, No 681, del viernes 17 de octubre de 1919, página 6.

Finalmente, al día siguiente apareció la noticia del día 16 de octubre, bajo el siguiente titular: «Dificultades para resolver la huelga de Lima; parece que han surgido grandes dificultades entre patronos y obreros para la reanudación del trabajo», en $E l$ sol, año III, Nº 682, sábado 18 de octubre de 1919, página 6.

Así, vemos que los madrileños estuvieron al corriente de los problemas internos de nuestro país los siguientes diez días después del deceso de nuestro tradicionista, pero no encontramos la noticia pertinente al luctuoso suceso. 
En las pesquisas realizadas en esta hemeroteca en el 2018 pudimos encontrar siete publicaciones: una de los Estados Unidos, cuatro de México, una de Chile y una de Argentina.

\section{Una noticia de Nuevo México}

En la profusa investigación de Carlos Arrizabalaga que hemos citado al inicio del presente artículo, el investigador palmista encontró una mención al deceso de Palma en un lugar tan remoto como los que hallé en mi investigación, es decir, los casos de Otawa, Illinois y Topeka, Kansas; es por ello que hemos decido incluir su hallazgo aquí, gracias a que nuestro colega nos ha remitido la imagen de la misma. Se trata de una noticia necrológica del deceso de nuestro tradicionista publicada en primera página de un semanario del entonces recién creado estado de Nuevo México, que desde el 6 de julio de 1912 era el $47^{\circ}$ estado de la Unión. Se trata de La Vox del Pueblo, de la ciudad de East, Las Vegas, en el condado de San Miguel, que le dedicó el $1^{\circ}$ de noviembre de 1919 una nota a la cual Arrizabalaga califica de «sentida» y que citó en su texto y transcribimos en el nuestro:

Acaba de fallecer en Lima, la bella capital del Perú, el gran literato Ricardo Palma, honra de América y notable entre los estilistas hispanoamericanos por su gran erudición y notabilísimos conocimientos. Ricardo Palma, cuyo libro las mejores tradiciones debería estar en casa de todo amante del idioma, fue durante muchos años director de la Biblioteca Nacional de Lima. Actualmente vivía casi retirado en el simpático pueblo de Miraflores donde entre mirlos y 
naranjos, a pesar de su avanzada edad, contemplaba desde su bella terraza el azul purísimo del Pacífico, y continuaba enriqueciendo el léxico castellano; descanse en paz el noble y castizo literato (Arrizabalaga, 2015, p. 23).

\section{Palabras Finales}

Hemos podido dar nuevas luces en cuanto al impacto del deceso de nuestro egregio patrono en seis estados de la Unión y en la capital de aquel país; asimismo hemos encontrado la noticia en los periódicos de las capitales de tres países hispanoamericanos, hoy mal llamada América Latina; visualizar las imágenes de dichas publicaciones nos ayuda a ver su importancia y es un primer esbozo del impacto mediático que tuvo su deceso en el mes de octubre y primeros días de noviembre de 1919. Debemos dejar constancia de que gracias a las pesquisas en la prensa hispana sabemos que allá se conocía la huelga que se vivió en nuestro país durante el deceso de Ricardo Palma, que es la respuesta al retraso que se dio en nuestro país para la publicación de las noticias de su deceso y los homenajes respectivos. Queda pendiente revisar los periódicos de los países del Caribe, Cuba y Puerto Rico, esta última isla donde fue tan leído en vida nuestro tradicionista, y localizar, si los hubo, algún obituario en medios de prensa de países centroamericanos como Guatemala y Nicaragua. 


\section{Referencias bibliográficas}

\section{Periódicos:}

New York Tribune, miércoles 8 de octubre de 1919. New York, USA.

Evening Star, martes 7 de octubre de 1919. Washington D. C. USA.

Norwich Bulletin, jueves 9 de octubre de 1919. Connecticut, USA.

Free Trader-Journal, martes 7 de octubre de 1919. Illinois USA.

Topeka State Journal, 7 de octubre de 1919, Kansas, USA.

El Universal, domingo 2 de noviembre de 1919. México D. F., México.

Excelsior, miércoles 8 de octubre de 1919, año III, Tomo IV, No 935. México DF, México.

El Demócrata, el miércoles 8 de octubre de 1919, México D. F., México.

El Mercurio, del viernes 10 de octubre de 1919. Santiago de Chile, Chile.

La Prensa, martes 7 de octubre de 1919. Buenos Aires, Argentina.

El Sol, Año III, No 673, del jueves 9 de octubre de 1919, España.

La vox del Pueblo, el 6 de julio de 1912, Nuevo México, USA.

\section{Libros y artículos:}

Arrizabalaga, C. (2015). «A Women scorned. Una temprana traducción de Ricardo Palma en la prensa de Estados Unidos». En Revista de la Facultad de Humanidades y Lenguas Modernas No 18, EneroDic., pp. 19-40. Lima: Universidad Ricardo Palma. 
Díaz Falconí, J. (1967). Ricardo Palma, personaje de sí mismo. Lima: Universidad Nacional Mayor de San Marcos.

Holguín Callo, O. (2001). Páginas sobre Ricardo Palma. Lima: Universidad Ricardo Palma.

Varillas Montenegro, A. (2016). «Estudio Preliminar». En Palma, R. El Demonio de los Andes, pp. VII-LXXXV, Lima: Academia Peruana de la Lengua.

Recibido el 25 de agosto de 2020 Aceptado el 27 de septiembre de 2020 